\title{
The Effectiveness of Boards of Directors in Nonprofit Organizations
}

\author{
Ladki SM and Ahmad FA* \\ Lebanese American University, Lebanon
}

\begin{abstract}
This paper investigates if board diversity and expertise impact innovation and effectiveness of hospitality nonprofit organizations (NPOs). Both agency and resource dependency theories suggest that the presence of a diverse board increase organizational performance. This study explores the innovation and effectiveness strategies of NPOs. Sample represents some of the most popular NPOs. Results of the null hypotheses conclude that organizational innovation and effectiveness are affected by board diversity and expertise.
\end{abstract}

Keywords: Nonprofit organizations; Boards of directors; Board diversity; Board expertise; Innovation; Effectiveness

\section{Introduction}

This paper investigates whether board diversity and board expertise impact innovation and effectiveness of nonprofit organizations (NPOs). Although several studies have been conducted to evaluate the board of directors' effectiveness, most have investigated the relationship between the board's performance and organizational effectiveness. Few studies have explored the effect of the board of directors' structure on organizational innovation [1]. In order to survive in a competitive market, organizations are striving to innovate and become pioneering. In business today, innovation is one of the most investigated topics.

The leadership and success of nonprofit organizations rely on the board of directors and management effectiveness [2]. From the management perspective, an NPO is a coordination of various components, such as board members, superior managers, volunteers, and clienteles [3]. Management and employees along with the board directors' methods of operations form the crucial core for the functioning and effectiveness of such organizations.

NPOs that aspire to be more innovative recruit board members who have served on boards of highly innovative companies and understand business complexities [4]. Such board members bring added value and competitive advantage, when sharing their tangible experience at board meetings. The insight provided by such members adds substantial contributions to innovation enhancement. The CEO of Stanley Works, John Trani, stated "the board adds value when it encourages out-of-the-box thinking". He further added that "when it comes to environmental shift, the board of directors can be specifically helpful in detecting blind spots where the CEO's experience is not in that area".

Experienced board members establish innovative expectations and identify strategic challenges encountered by NPOs. The board encourages innovativeness through the creation of an organizational culture that embraces innovation. If an organizational experiment on creativity or the launching of a new product doesn't succeed, the board's response is critical. The decision is either to fire those responsible or to give them another chance. "Unless some tolerance for failure begins to permeate the culture, all those corporate screen-savers flashing the word "Innovate" will achieve little more than eye rolling" [5]. The board of directors' main duty or focus is to guide innovation and modernization, however, without dampening the corporate culture's inventive spirit [4].

\section{Literature Review}

Numerous studies have reported about the board of director's role in influencing organizational innovation [6,7]. It is well documented that innovative boards have enhanced organizational performance. Getting involved in innovative thinking and supporting management to pursue innovation are organizational essentials (Figure 1). The professional networks of board members benefit NPOs in public awareness and fund-raising [8]. Boards are able to stimulate innovation in the organization without really presenting innovations. They ensure innovativeness by: establishing an environment that embraces innovation, setting innovative priorities and goals, offering autonomy to generate new ideas, pursuing improvement, and tolerating new proposals [9]. Several experimental evidences describe the board's ability to smooth the diffusion of innovations, by not only offering advice but also initiating strategic actions [10].

The resource dependency theory and the agency theory emphasize the ability of the board of directors in encouraging and facilitating innovation [11,12]. The resource dependency model considers the survival of NPOs highly depends on environmental resources. Board members facilitate the acquisition of resources and provide linkages (linking the NPO with stakeholders, providing expertise, managing assistance and counsel, strengthening the public image of the NPO,

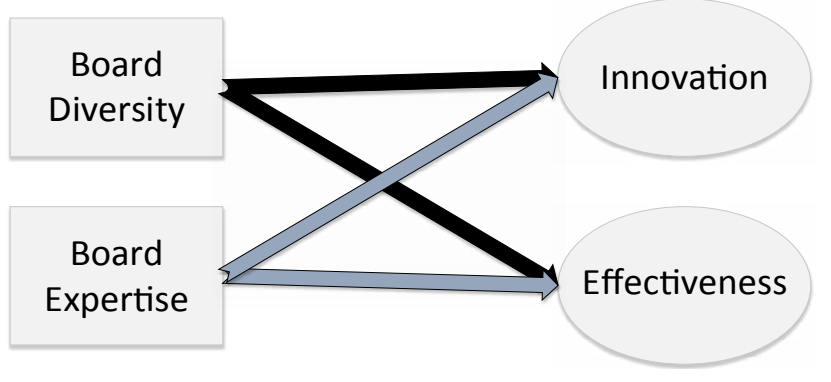

Figure 1: Organizational innovation and effectiveness.

*Corresponding author: Ahmad FA, Lebanese American University, Beirut, Lebanon, Tel: +9611786456; E-mail: fatme.ahmad@lau.edu

Received March 26, 2018; Accepted May 01, 2018; Published May 10, 2018

Citation: Ladki SM, Ahmad FA (2018) The Effectiveness of Boards of Directors in Nonprofit Organizations. J Bus Fin Aff 7: 332. doi: 10.4172/2167-0234.1000332

Copyright: @ 2018 Ladki SM, et al. This is an open-access article distributed under the terms of the Creative Commons Attribution License, which permits unrestricted use, distribution, and reproduction in any medium, provided the original author and source are credited. 
and building exterior relations), all of which are desirable to foster innovation $[13,14]$. The board of directors accelerates innovation by reducing the dependency on the external environment, as well as providing consultancy and guidance to the executive director [15].

Furthermore, the agency theory suggests that the most important board's function is the internal control. Board of directors contributes to organizational performance by understanding and adopting stakeholders' goals and objectives, directing the managers' attention toward strategic decisions, performance control, and organizational performance [16]. Besides its strategic governance and fiduciary roles, the board of directors interferes in "generative governance" [17]. Thus, the board generates better understanding of challenges facing the organization, realizes new opportunities that require variations in beliefs, values, and behaviors, proposes several hypotheses, and highlights different opportunities.

Although there is a great consensus that the board of directors' characteristics are significant, literature regarding this issue continues to be limited [18]. Studies on boards and innovation have been narrow because most governance theories have not incorporated a thorough innovation analysis, and the practical innovation enquiries have disregarded the board roles [1,19-21]. Despite the growing literature concerning boards of directors and publicly entrepreneurial establishments [22], most of the investigations have focused on board activities and governance challenges, instead of board's characteristics that influence organization's ability to innovate.

\section{Board Diversity}

Both the agency theory and the resource dependency theory suggest that the presence of a diverse board increase organizational performance. Varied backgrounds (ethnicity, gender, or age) offer fresh and different perspectives and viewpoints which are not highlighted or stressed by homogenous boards [23]. The "National Association of Corporate Directors" emphasized on the importance of sex, age, race, and nationality variety in board selection [24].

The board of director's composition is viewed as a very substantial issue by many corporations. The CEO of Sun Oil, Robert Campbell, stated: "A woman or a person from a minority group brings to the board of director's numerous perceptions that a firm has not had formerly. Those viewpoints are of substantial added value and are usually absent from pure white-male board members. They are furthermore able to inspire the company's workforce" [25].

The board of directors is the policy-maker that ensures the presence of the adequate resources to advance NPOs' mission and guides NPOs towards a sustainable future. The board's structure greatly impacts policy and services' delivery, provides a protection to the resources [26] and ensures the conformity to the laws for NPOs [27]. The contribution of a diverse and representative board paves the way to further shared values of responsiveness, effectiveness, and accountability.

Board diversity influences the success of non-profit organizations. "The need for a diverse board not only facilitates effective decisionmaking and delivering appropriate services but also stimulates creativity and innovation" [28]. The public research foundation, Greenlining Institute, stated that a heterogeneous board is the most effective when responding to diverse needs [29]. Heterogeneous groups are superior at answering ambiguous problems through developing creative solutions $[30,31]$.

A report brought by the "California Public Employees' Retirement
System" [32] indicated that firms that are sensitive to ethnic and gender diversity outperform those who lack representation. Traditionally, nonprofit boards of directors were incorporated mainly of upper and middle-class white members. Precisely, Ostrower found in a survey done on more than 5,100 nonprofit organizations that white members comprise about 86 percent; African Americans constitute 7 percent; and Hispanics represent 3.5 percent of her sample boards of directors [33]. Also, she found that 18 percent of nonprofit boards include no African American members despite the fact that 50 percent of their beneficiaries are of African American origin. Ostrower further stated that boards of directors with less heterogeneity have difficulty in serving the various needs of the residents [33]. Diversified boards are better at having certain accountability measures especially external audit committee and whistleblower policies. Ostrower's study also involved consequences of having gender mix on the boards of NPOs. She emphasized on several aspects (including funding resources, knowledge of the nonprofit's mission, geographic focus, and other organizational characteristics) that are directly and positively correlated with the proportion of female board directors [33].

A heterogeneous board expands the pool of donors and allows the nonprofit organization to appeal to larger audience. The proportion of minority members serving on the board is highly related with the donations contributed to the NPO. That is, nonprofits are able to accumulate more donations and government grants when their boards incorporate larger proportion of minority members. Therefore, NPOs with ethnic, gender, and age diversity on their boards of directors proves to be associated with additional earnings [23,34-36]. The nonprofit organization ensures its agency success when it announces diversity among its board members.

\section{Board Expertise}

Boards are in charge of the governance of nonprofit organizations and they ensure compliance with all ethical and legal codes. Legal, governance, and ethical responsibilities require keen financial understanding and insight. The presence of board members who are familiar with budgets, financial statements, and nonprofit tax law is of utmost importance. Applying for grants, fundraising, the timing of funding proposals, implementing capital reserve funds, monitoring the investment policy, and thorough financial judgment are basic requirements. Accounting and financial knowledge of the NPO's board, is of significant necessity especially following the update of the requirements of financial statements reporting and the extension of nonprofit tax returns (IRS form 990). Boards should be prudent about the usage of all NPO's assets and ought to comply with the requirements of IRS and state laws. It's notable that if the IRS accuses any falsified act or even if a donor files a legal complaint for mismanagement of his own contributions, the entire board is held responsible.

Financial Accounting Standards Board (FASB) requirements for nonprofit financial statements are becoming stricter than before. Nonprofit financial statements are bounded with firm requirements promulgated by the FASB especially regarding tax returns and audits. Also, when preparing financial statements, NPOs must sort expenses by their function as of administrative, software development, and fundraising. These updated requirements help the public better review the organization's financial reports and their disbursement amounts and activities. However, such statements require adjunct effort exerted by a financial expert operating on the board that ensures that these new FASB requirements are implemented.

Financial experts who have served on other nonprofit boards have 
usually acquired the necessary knowledge on financial reports and became familiar with the generally accepted accounting principles (GAAP). These proficient experts contribute to board effectiveness through setting and analyzing budgets and ensuring that all items are recorded and reported properly. They innovatively conduct fundraising activities in different states and plan for potential losses of grants. Board members who are familiar with the industry are usually more aware of the governance problems that the NPO usually encounter. Mixing proficient board members with members who have not served on a board previously helps the latter adopt new strategies and facilitates problem-solving and decision making.

Experts considered General Motor's board of directors to be ineffective because its members lack the adequate automobile industry experience [37]. Also, empirical research indicated that NPOs that incorporate a financial expert in their audit committee are able to obtain more government grants and to have a superior internal auditing [38]. Based on these findings, the success and survival of an NPO is associated with the presence of financial expertise. Nonprofit research also stresses the advantages of previous volunteer work, fundraising, and monitoring on the continuity of the nonprofit organizations [33]. These findings indicate that individuals currently or formerly serving on other nonprofit boards are capable of bringing further business information, understandings, and networking to boards of directors.

Therefore, the paper assumes that the null hypotheses $(\mathrm{Ho})$ are:

Ho: There is no direct relationship between board diversity and organizational innovation

Ho: There is no direct relationship between board diversity and organizational effectiveness

Ho: There is no direct relationship between board expertise and organizational innovation

Ho: There is no direct relationship between board expertise and organizational effectiveness Methodology.

This qualitative study explores the innovation and effectiveness strategies of NPOs. Sample represents some of the most popular NPOs. Study was conducted by MBA students at the Lebanese American University, Adnan Kassar School of Business. Though there are hundreds of NPOs, the researchers focused on the top NPOs that provide food, shelter, and other services. The researchers evaluated if NPOs' innovation and effectiveness strategies are functions of board diversity and board expertise. The dependent variable in this study is NPOs' innovation and effectiveness. The independent variables are board diversity and expertise.

\section{Results}

\section{Salvation army}

The Salvation Army is one of the most renowned international charitable establishments that is founded in 1865. This Christian church possesses a widespread membership of above 1.5 million Salvationists involving officers and supporters present in 127 countries. The aim of this NPO is to attain salvation to the needy and hungry by satisfying their "physical and psychological needs". The Army controls several charity divisions, supplies homeless with shelters, and offers humanitarian aid and disaster relief to many deprived countries. A wide range of social services are delivered by the Salvation Army such as: food for the hungry, shelter to the homeless, assistance to the elderly and ill, and aid for the disabled.
The Salvation Army is a main provider of social aid around the world, serving over 31 million people in the United States alone. The Army operates in 7,551 different centers covering almost every ZIP code in the country. In addition to disaster relief and community centers, the Army works in refugee sites to help displaced people, particularly in Africa and other developing countries. The American Institute of Philanthropy (AIP) rated the Army with an "A-" ranking.

The Army has been serving people and offering significant services for more than 150 years internationally and particularly for around 120 years in the U.S. As stated by The New York Times, "Among nonprofit organizations, The Salvation Army is vastly identified exemplary especially in managing donations and collections."

\section{Charity water}

Charity Water is one of the top nonprofit organizations that provide clean potable water to citizens of developing countries. This NPO was established in 2006 and has helped finance around 20,000 projects in more than 20 countries. The charity funds numerous water programs benefiting over 6.1 million people in Asia, Africa, South and Central America.

Around the world, 663 million people ( 1 in 10 people) live without clean water. The majority lives in remote and inaccessible rural regions and spends several hours walking to provide their families with potable water every day. Along with wasting time and keeping kids out of school, walking for water is often carried with harmful diseases. Charity Water Organization strives to make clean water accessible to poor citizens, thus helping them use time to earn money, to be educated, and to stay healthy especially for women and kids.

Charity water funds new wells and extends its activities to after service operations through the continuous checkup on the wells already established. This is how the charity ensures that its projects continue to offer clean and safe water to populations even after they are installed. In order to maintain the flow of water at charity water projects, proficient mechanics, local and trained leaders and innovative technology coordinate their work through a system known as Pipeline.

\section{Barilla center for food \& nutrition foundation}

The Barilla Center for Food \& Nutrition Foundation (BCFN Foundation) is a private non-profit organization. The foundation provides valuable and scientific information and data to societies about food and nutrition, health and sustainability.

BCFN promotes the wellbeing of individuals through: offering nutritionally balanced products, providing people with correct information on sustainable food choices, educating the youth through educational projects, promoting healthy lifestyles, and fostering sustainable growing and production models that respect the rights of people, animals, and the planet from field to consumption. The foundation also promotes diversity and includes it both inside the company organization (including its board of directors) and in the local communities where it is present.

\section{Habitat for humanity}

Habitat for Humanity is a global, non-governmental, and nonprofit organization, which was established in 1976. Habitat for Humanity has been committed to build "decent, simple, and affordable" accommodations, and has been concerned with the issues of poverty housing around the world.

Habitat for Humanity allies with individuals in the society, and 
around the world, to help them construct or even improve their homes. Habitat homeowners help construct their own shelter alongside volunteers and pay a reasonable mortgage. Today Habitat for Humanity has aided over 1 million families in need around the world, finishing the construction or repair of homes. Through its 2020 Strategic Plan, Habitat for Humanity will help more people than ever before through ensuring suitable and inexpensive housing.

Habitat for Humanity builds strength, stability, and independence in partnership with families in communities across the United States and Canada. Habitat for Humanity operates in Puerto Rico, Columbia, all U.S. states, and U.S. Virgin Islands. In Canada, Habitat for Humanity has 56 active Habitat affiliates in each of the 10 provinces and in all the three territories. Each independent local affiliate manages and organizes construction in its region and selects partner individuals and families disregarding their race, ethnic group, and religion.

\section{Discussion}

\section{Salvation army}

One reason behind the ability of the Salvation Army to support those in need in the United States and over 100 countries for more than 130 years is due its diversed board membership.

The board of directors serves as a liaison between The Salvation Army and the community. The board constantly innovates to increase the visibility of the organization and accordingly increase its interaction with the community. The Salvation Army's National Board members voluntarily use their professional and leadership skills and knowledge to assist The Salvation Army. These diverse board members make a significant difference on The Salvation Army's capability to serve communities in need.

The board members also function as interpreters. They help The Salvation Army better understand the community's pulse, character, and needs. This will deliver better understanding for developing appropriate programs and funding resources. Due to the dynamic and technological revolution, The Salvation Army was struggling to expand because people were increasingly shopping online instead of using traditional methods such as catalogues. The board members of the charity then decided to move to direct mail instead of running television campaigns in 2003 and that achieved better results.

Increased interaction and community involvement expanded The Salvation Army donor's base and community reach out. An effective method that the board of The Salvation Army has set is by hiring those who may have criminal records or who are ex-addicts. Through this Adult Rehabilitation Center, The Salvation Army houses 120 with life issues, rehabilitates them, and helps them get a job.

In 2016 alone, The Salvation Army provided: 54,000 meals, 13,000 nights of lodging, 1,300 emergency food boxes, 2,200 individuals with clothing, 3,177 persons with financial aid, 3,600 gifts of necessities for the poor and elderly, and 2,435 gifts and clothing to families. These donations, along with numerous other services that involved disaster assistance, youth enrichment programs, camp opportunities for youth, and classes in life skills were provided through the Angel Tree Program.

In 2015, The Salvation Army's 3,500 officers, 65,000 workers, and 3.2 million volunteers served more than 25 million needy people only in America. That's almost one individual, every second, every day.

\section{Charity water}

Charity Water's board of directors is diverse and highly experienced.
The board is composed of Scott Harrison (Former Founder \& CEO at Charity Water), Michael Wilkerson (CEO \& Director at Fairfax Africa Holdings Corp.), Chi-Hua Chien (Co-Founder at Goodwater Capital LLC), Brant Cryder (President at Yves Saint Laurent of America, Inc.), Shannon Sedgwick Davis (CEO at Bridgeway Charitable Foundation), Valerie Donati (Global Executive at C3 International LLC), Gian-Carlo Ochoa (Venture Partner at Andre Meyer Group), Brook Hazelton (President, Americas at Christie Group Plc). Board members have rich backgrounds in different industries and organizations and possess high connections and interpersonal relationships.

Charity Water is outstanding at inbound marketing through creating influential means to inspire people to join their noble cause. One of the most powerful ways is by forming an accessible online platform that permits individuals to produce diverse fundraising campaigns such as marathons and holidays that are linked to specific events. In 2012, Charity Water was able to raise $\$ 33$ million, of which over $\$ 8$ million was through the help of the online fundraising platform. In 2015, the community collected about $\$ 35$ million and gave safe drinking and clean water to more than 800,000 families and individuals.

The decision of the Charity Water's board members to partner and cooperate with popular celebrities (such as Adrian Grenier and Will and Jada Smith) and famous brands (such as American Express, Toms, and Nautica) facilitated the charity's ability to magnify its message and influence audience and donors. These major brands and public figures advertise the charity through their products and they mention the nonprofit organization on websites and social media. For example, Toms, a company that designs and sells shoes and eyewear, launched limited edition charity water glasses and shoes.

Also, thanks to the board of directors of Charity Water, the community is the first ever charity accepting donations on Facebook Messenger. They believe it is one of the simplest ways people can donate on mobile. Charity Water has become one of the best and innovative charities when it comes to using social media to engage and inspire audience and raise funds. By giving people the facility to donate on Facebook Messenger, the organization makes it easier than ever to help bring clean and pure water to the 663 million individuals living on earth without life's most basic need. Charity Water's CTO Matthew Eckstein said that the Facebook Messenger bot had been designed to feel "as close as possible to that of donating on our own website." He added that "As an organization with a very young and tech-savvy supporter base, it's important that we continuously adapt to reach them as they adopt new technologies and social platforms".

\section{Barilla Center for Food and Nutrition Foundation}

The Board of BCFN is composed of internationally renowned females and males scientists and experts working in different industries. The board members of BCFN are President Guido Barilla, the two Vice Presidents, Paolo Barilla and Luca Virginio, and other members (Anna Ruggerini, Roberto Ciati, Alberto Grando, Carlo Petrini, Lucio Riva, and Paolo De Castro).

The board pays close attention to current and emerging society needs related to food and nutrition and offers solutions for improved food security and healthy and sustainable nutrition. It also develops concrete proposals and recommendations about nutrition and health and makes them available to all the major decision makers in order to promote better quality of life and wellbeing for all people.

The Board of Directors is the group assigned with the most 
extensive influences for the ordinary and extraordinary management of the NPO. It is responsible for defining the management direction, evaluating the appropriateness of the organizational structure and the management's performance.

It is notable that 219 products were reformulated to improve Barilla's nutritional profile since 2010 till 2016. The emissions of carbon dioxide gas $\left(\mathrm{CO}_{2}\right)$ were reduced by $23 \%$. Besides, water consumption per ton of finished product declined by $19 \%$ compared to 2010 .

\section{Habitat for humanity}

Habitat for Humanity's universal success returns to a diverse board of directors who assumes that all individuals equally deserve a place to live in. The board is responsible for forming policies and for managing Habitat for Humanity's effort to repair, improve, and build housing in nearly 70 countries. The board members are in charge of the effective governance of Habitat for Humanity and act in positions of trust for the society.

Habitat for Humanity is managed by the Chairman Joe Price (Previous President at Bank of America), the Vice Chairs Mary Staley (Volunteer and Philanthropist), Henry Cisneros (Current Chair at City View), Jonathan Reckford (CEO of Habitat for Humanity International), Cary Evert (President of CEO of Hilti), Bill Brand (President and CMO of HSN), Alberto Harth (President of Civitas), Celso Marranzini (President of Multiquímica Dominicana), Bradford Hewitt (President and CEO of Thrivent Financial for Lutherans), Jimmy Masrin (CEO of Caturkarsa Megatunggal), Mary Cameron (Corporate Director), David Fischer (Former President and CEO of Greif), Lisa Hall (Managing Director), Alexandre Gouvea (Partner and Consultant at McKinsey \& Co.), Jessica Jackley (Investor and Advisor), Bo Miller (Co-Founder and Principal), Koome Kiragu (Leoma Properties), , Jackie Parker (President and Director of General Motors Foundation), Scot R. Sellers (Former CEO of Archstone), Jim Stanard (Former Chairman and CEO of RenaissanceRe), Ron Terwilliger (Retired Partner of Trammell Crow Residential), and Ramez Sousou (CEO of TowerBrook Capital Partners). The effects of this highly diversified and well-experienced board of directors are significantly reflected on the innovative and efficient solutions to help those in need.

Habitat for Humanity in Romania, along with one of its corporate partners ArcelorMittal, has been developing energy efficient and environmentally friendly light steel frames. These frames can be easily established into a house and recycled upon deconstruction for other needs. Also, compared to other materials, steel frames are more energyefficient and they have a superior thermal performance. They prevent heat loss during winter and retain cool temperature during summer.

The lack of access to clean water and sewage systems in many communities of Kyrgyzstan's rural areas pushed Habitat for Humanity to establish a simple eco-toilet that is assembled by using local resources. This innovative, environmentally-friendly, and affordable solution offers sanitary and clean toilet conditions without polluting the soil and water. The eco-toilet transforms the waste products into nontoxic composts which are used then as fertilizers.

\section{Conclusion}

Though it is most convenient for any nonprofit organization to recruit board members from its pool of members and associates, this is not always the best idea. The board's primary function is to ensure that the organization fulfills its commitment and responsibility towards the community as indicated in its mission, code of ethics, and charter. Diverse viewpoints and experience benefit the board of directors when developing policies regarding whistleblowers, conflicts of interest, financial auditing, and management. They further create an environment that embraces creativity and innovation.

Diversity induces an effective and innovative board functioning by enriching problem and needs assessment, enhancing decision-making action strategies, improving the quality of strategic thinking, and contributing to effective program implementation. When each group of clientele is represented by at least one board member, the nonprofit organization becomes more responsive to the societal needs.

While diversity alone won't lead to success, necessary measures are taken to set up the board for success by implementing a selection process, adopting governance policy, and investing in workforce training. These steps foster an environment of inclusion for the organization's other aspects and long term performance. The impact will exceed staff, even increasing diversity in the volunteer forces. Boards of directors with cultural, gender, ethnic, and expert diversity tend to have a more diverse leadership cadre, eventually resulting in various resources.

\section{References}

1. Wu HL (2008) How do board-CEO relationships influence the performance of new product introduction? Moving from single to interdependent explanations. Corporate Governance: An International Review 16: 77-89.

2. Howe F (2004) The Nonprofit Leadership Team: Building the Board-Executive Director Partnership.

3. Anheier K (2000) Managing Non-Profit Organisations: Towards a New Approach.

4. Behan B (2014) Innovation starts in the boardroom. Directors and Boards, pp: 29-31.

5. Jaskyte K (2009) Innovation in human service organizations. Human services as complex organizations, pp: 481-503.

6. Jaskyte K (2012) Boards of directors and innovation in nonprofit organizations. Nonprofit Management \& Leadership 22: 439-459.

7. Wu HL, Lee CY (2007) The effects of board competence on operational innovation: tests of universal, contingency and configurational models. International Journal of Technology Management 39: 330-345.

8. Nicholson GJ, Kiel GC (2004) A framework for diagnosing board effectiveness Corporate Governance: An International Review 12: 442-460.

9. Daft RL (1978) A Dual-Core Model of Organizational Innovation. Acad Manage J 21: $193-210$

10. Davis GF (1991) Agents without principles? The spread of the poison pill through the intercorporate network. Administrative science quarterly, pp: 583613

11. Pfeffer J, Salancik GR (1978) The External Control of Organizations: A Resource Dependence Perspective. Harper \& Row, New York.

12. Fama EF, Jensen MC (1983) Separation of ownership and control. J Law Econ 26: $301-325$

13. Hillman AJ, Dalziel T (2003) Boards of directors and firm performance: Integrating agency and resource dependence perspectives. Acad Manage Rev 28: 383-396.

14. Miller-Millesen JL (2003) Understanding the behavior of nonprofit boards of directors: A theory-based approach. Nonprofit and Voluntary Sector Quarterly 32: $521-547$

15. Huse M (2007) Boards, governance and value creation: The human side of corporate governance. Cambridge University Press.

16. Mizruchi MS (1983) Who controls whom? An examination of the relation between management and boards of directors in large American corporations. Acad Manage Rev 8: 426-435. 
Citation: Ladki SM, Ahmad FA (2018) The Effectiveness of Boards of Directors in Nonprofit Organizations. J Bus Fin Aff 7: 332. doi: 10.4172/21670234.1000332

17. Chait RP, Ryan WP, Taylor BE (2005) Governance as Leadership: Reframing the Work of Nonprofit Boards.

18. Ostrower F, Stone MM (2006) Governance: Research trends, gaps, and future prospects. The nonprofit sector: A research handbook 2: 612-628.

19. Markman G, Balkin D, Schjoedt L (2001) Governing the Innovation Process in Entrepreneurial Firms. Journal of High Technology Management Research 12: $273-293$

20. Miozzo M, Dewick P (2002) Building competitive advantage: Innovation and corporate governance in European construction. Research Policy 31: 9891008.

21. O'Sullivan M (2000) The Innovative Enterprise and Corporate Governance. Cambridge J Econ 24: 393-416.

22. Light $P$ (2008) The Search for Social Entrepreneurship. Brookings Institution Press.

23. Carter DA, Simkins BJ, Simpson WG (2003) Corporate governance, board diversity, and firm value. Financial review 38: 33-53.

24. National Association of Corporate Directors (1994) Report of the NACD Blue Ribbon Commission on Value Evaluation of Chief Executive Officers, Board, and Directors. Washington, D.C.

25. Campbell RH (1996) CEO vs. Nun: It's a Draw. The Wall Street Journal.

26. Provan K (1980) Board power and organizational effectiveness among human service agencies. Acad Manage J 23: 221-236.

27. Siciliano JI (1996) The relationship of board member diversity to organizational performance. Journal of Business Ethics 15: 313-132.
28. Board Source (1999) Perspectives on Nonprofit Board.

29. González-Rivera C (2009) Diversity on foundation boards of directors. Greenlining Institute.

30. Bantel KA, Jackson SE (1989) Top management and innovations in banking Does the composition of the top team make a difference? Strategic Manage J pp: 107-124.

31. Michel JG, Hambrick DC (1992) Diversification posture and top management team characteristics. Acad Manage J 35: 9-37.

32. CalPERS (2009) Global Principles of Accountable Corporate Governance. California Public Employees' Retirement System.

33. Ostrower $F$ (2007) Nonprofit governance in the United States: Findings on performance and accountability from the first national representative study.

34. Fields MA, Keys PY (2003) The emergence of corporate governance from Wall St. to Main St.: Outside directors, board diversity, earnings management, and managerial incentives to bear risk. Financial Review 38: 1-24.

35. Keys PY, Ellis KM, Newsome PT, Friday S (2002) Shareholder benefits of diversity. Journal of Accounting and Economics 33: 375-400.

36. Wright P, Ferris SP, Hiller JS, Kroll M (1995) Competitiveness through management of diversity: Effects on stock price valuation. Acad Manage J 38: 272-287.

37. Lublin JS (2009) GM Will Replace at Least Six Others on Board. Wall Street Journal.

38. Forgione D, Vermeer T, Raghunandan K (2006) The Composition of Nonprofit Audit Committees. 